However, the other signs are not found in other Jawi manuscripts and are M. Bakir's own invention. In some other Indonesian languages the same system to indicate vocals with special marks is applied when using the Arabic alphabet like pegon and Buri Wolio writings. M. Bakir's efforts indicate that he considers the Jawi alphabet not quite perfect. The question then is: how readable was Bakir's manuscript for his readers? Is it possible that he suspects that some of his readers would have been unable to read Betawi words?

Chambert-Loir considers Bakir's spelling quite good: words originating from Arabic are written with etymological spelling, although there are several deviations. Words considered originating from a foreign language (in this case Sanskrit) are written with consideration of their original sounds (in this case sy). But a hypercorrect trend is also present: besar (big) is written besyar; this, however, is quite common in Old Malay manuscripts. The morphology and syntax of the text reveal the influence of various languages, specifically informal Betawi dialect as well as several other languages. When using words that are not Malay, the author often provides (sometimes faulty) explanations and translations. This is not found in other Malay manuscripts.

Chambert-Loir's work explores a unique literary process and its cultural background in the process of undergoing a profound change which is Batavia moving from traditional to modern. M. Bakir, as one of its representatives, is an active participant in this process who translates all the restlessness of his time into words in a creative and original way. Chambert-Loir's research awakens our interest to further unearth and analyse other undetected gems in the literature of Nusantara.

Mu'jizah, Iluminasi dalam surat-surat Melayu abad ke-18 dan ke-19. Jakarta: Kepustakaan Populer Gramedia, École française d'Extrême-Orient, Pusat Bahasa-Departemen Pendidikan Nasional, and KITLV-Jakarta, 2009, 204 pp. [Seri Buku Pustaka hikmah Disertasi (PhD) 2.] ISBN 978-979-91-0175-4. Price: IDR 70,000 (soft cover).

\title{
Dewaki Kramadibrata
}

Faculty of Humanities, University of Indonesia dewaki.kramadibrata@ui.ac.id

In 1991, a bilingual book entitled Golden Letters: Writing Traditions of Indonesia; Surat Emas: Budaya Tulis di Indonesia (Annabel Teh Gallop and Bernard Arps) was published. It contains many illustrations of letters in Malay and Javanese written by Nusantara kings to European and other rulers in the past. Subsequently, in 1994, a book entitled The Legacy of the Malay Letter; Warisan Warkah Melayu (Annabel Teh Gallop) was published. Since 


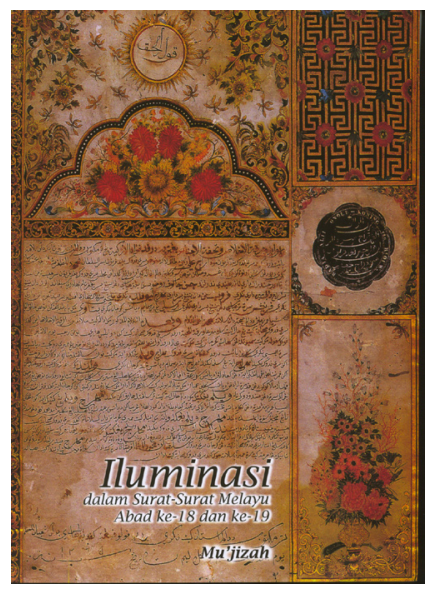

then, few other researches on Malay letters have seen the light. One of them is a study on Malay letters written by Mu'jizah in 2006 as a doctoral dissertation entitled Surat Melayu Beriluminasi Raja Nusantara dan Pemerintah Hindia Belanda Abad XVIII - XIX: Tinjauan Bentuk, Isi, dan Makna Simbolik at the Postgraduate Program of the University of Indonesia. Initially, the dissertation contained eight chapters totalling 389 pages. With some changes, this dissertation was published in 2009 under the title Iluminasi dalam surat-surat Melayu abad ke-18 dan ke-19.

The book consists of three chapters and ends with a conclusion, bibliography, and appendices which contains an index and biography of the persons mentioned in the letters, a table of all 50 illuminated letters, a list of photos, a list of manuscripts according to its institution, a summary, and an abstract in English. The first chapter provides a research background of illuminated letters which, in the past, were used as a means of communication between the Nusantara kings and the Colonial governments. Illumination is a technical term in the science of manuscripts (codicology) to refer to decorative drawings in manuscripts.

In her research, $\mathrm{Mu}^{\prime}$ jizah reveals the beauty and the variation in the decorative patterns used in Malay illuminated letters. For this purpose, she has chosen 50 illuminated Malay letters that are preserved in three places: the National Archives, Jakarta, the Library of Leiden University in the Netherlands, and the Library of the Koninklijk Instituut voor Taal-, Land- en Volkenkunde (KITLV), also in Leiden, the Netherlands. The letters originate from (1) the Riau peninsula including Johor, Pahang, and Terengganu; (2) Sumatra including Aceh, Riau, Lingga, and Palembang; (3) Java including Banten, Batavia, Bogor, Surabaya, and Madura; (4) Kalimantan including Mempawah, Pontianak, and Banjarmasin; and (5) Sulawesi including Tanette and Gorontalo. The letters cover the time span between 1791 and 1886.

In Chapter 2, we are presented with descriptions and transcriptions of the texts of the letters. All letters are written in Malay using Jawi script while a number of words and sentences are written in Arabic. All letters contain elements of calligraphy, especially in the title head (which is in Arabic) and in the last sentence (in Malay). In accordance with the philological tradition, the letters have been transcribed using the critical editing method (see Robson 1994: 25) to enable the reader to understand the contents of the text. Thus, $\mathrm{Mu}^{\prime}$ jizah as editor has provided an edition of the texts using the Latin alphabet with added punctuations while photographs of every letter are provided as well. Although the quality of the pictures is not as beautiful as those in Illuminations; The writing traditions of Indonesia (Kumar and McGlynn 1996), this method of presentation makes it very easy for researchers to read and compare the transcribed texts, while at the same time enabling them to enjoy 
the beauty of the letter's illuminations. Mu'jizah has attempted to present the transcripts with accuracy and diligence, and her efforts deserve praise.

Even so, she made mistakes in her transcripts. For instance, the word "tusk" (gading) is transcribed as "gadang": Suatu pun tiada tanda ikhlas dan suci hati hanyalah gadang dua pasang dan kain gulung sepasang [...] (There was no sign of sincerity and purity of heart except for two pairs of gadang and a pair of rolled cloth [...]) (p. 27). Compare this to Suatu pun tiada ada tanda hayati hanyalah kain Cina Kantun sepasang dan gading sepasang [...] (There was not one sign of sincerity but for a pair of Chinese Cantonese cloth and a pair of tusks [...]) (p. 30). Apart from that, I detected several spelling mistakes, such as in the spelling of "Traktaat London" (p. 15, whereas in p. 14 she uses "Traktat London"), and the word "bingkai" (frame) is printed as "bingai" (p. 33).

Chapter 3 explains the arrangement, characteristics, and function of the illuminations in the letters. Based on her analysis, $\mathrm{Mu}^{\prime} \mathrm{jizah}$ explains that there are three types of illumination in the letters of Nusantara rulers: spread style, and three- and four-sided illuminations. These letters, depending on their origin, also show typical characteristics in the illuminations of the framework and in other patterns. For example, the special characteristic of a letter from Palembang is the golden bamboo shoot pattern and calligraphy that resembles hearts. Letters from the Dutch Indies government are characterised by the fact that the framework lies within the frame bordering the area inside and the text border. The decorations on the sides are also typical, among others because of their dispersion of gold and gold trees, which are sometimes interspersed with small golden circles. Unfortunately, this section does not discuss the function of the illuminations as indicated in the chapter's title.

These discrepancies notwithstanding, the book is a tool of reference for researchers in philology, linguistics, and history. The text transcripts presented provide a historical description of the past. The different contents of the letters, such as the condolences offered on the death of King William II, requests for arms shipment and trade permissions, shows that letters may be seen as a means to express various different interests. It is also interesting to analyse the vocabulary found in these letters from a language point of view. For example, the use of the words gurnadur jenderal for gubernur jenderal (governor general), the variations in mentioning the area under Dutch colonial rule in Batavia: [...] yang bersemayam di atas kerajaan negeri Betawi (seated as head of the kingdom of Batavia) (p. 39), [...] yang semayam di dalam istana Bogor di atas takhta kerajaan dalam negeri Betawi (seated on the throne in the palace of Bogor in the kingdom of Batavia) (p. 44); [...] yang bersemayam di atas takhta singgasana kerajaan di dalam daerah Bandar negeri Betawi (seated on the throne of the kingdom in the Harbour of the country of Batavia) (p. 47).

Finally, as stated on the back cover, this book contains important information because "the letters are at the same time important documents for local history, as they contains various information in various fields, such as diplomatic business, political situations, trade, while they reflect the complexity of the relations between Nusantara kings and the Dutch government". 


\section{REFERENCES}

Gallop, Annabel Teh. 1994. The Legacy of the Malay Letter; Warisan Warkah Melayu. With an essay by E. Ulrich Kratz. London: British Library.

Gallop, Annabel Teh and Bernard Arps. 1991. Golden Letters: Writing Traditions of Indonesia; Surat Emas: Budaya Tulis di Indonesia. London: British Library, Jakarta: Yayasan Lontar.

Kumar, Ann and John McGlynn (eds). 1996. Illuminations; The writing traditions of Indonesia. Jakarta: The Lontar Foundation, New York: Weatherhill.

Robson, S.O. 1994. Prinsip-prinsip filologi Indonesia. Jakarta: Rijksuniversiteit Leiden and Pusat Pembinaan dan Pengembangan Bahasa.

Oman Fathurahman, Tarekat Syattariyah di Minangkabau; Teks dan konteks. Jakarta: Prenada Media Group, École française d'Extrême-Orient, Pusat Pengkajian Islam dan Masyarakat (PPIM) UIN Jakarta, and KITLV-Jakarta, 2008, 185 pp. [Seri Buku Pustaka hikmah Disertasi (PhD) 1.] ISBN 978-9793464-43-5. Price: IDR 45,000 (soft cover).

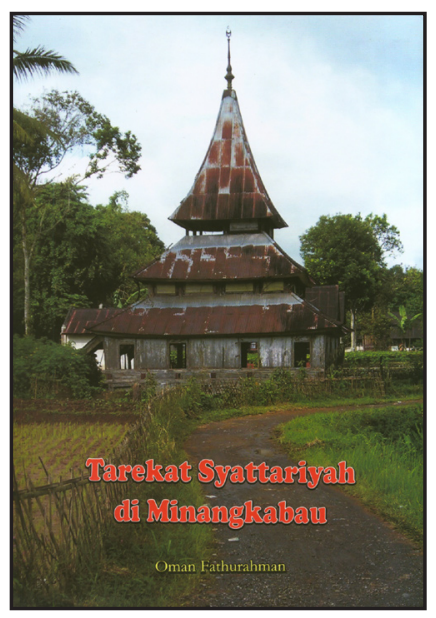

Eka Meigalia

Oral Traditions Association eka_meigalia@yahoo.com

adat basandi syarak, syarak basandi kitabullah

[tradition based on canonic law, canonic law based on the Book] syarak mangato, adat mamakai [canonic law states, tradition utilizes]

The above is a proverb in Minangkabau culture, which indicates the relationship between tradition and Islam. Because of the strong relationship between the two, Islam has become the main component of the "ethnical identity" of the Minangkabau people. This means that when someone proclaims him- or herself to be a Minangkabau citizen, s/he is definitely a Muslim; similarly, if one is not a Muslim one should not declare oneself as a Minangkabau citizen.

Islam and Minangkabau tradition have become inseparable ever since the teachings of Islam entered the Minangkabau region. The cultural area of Minangkabau in the Province of West Sumatra has a long history related to the influence of the Islamic religion in the lives of the Minangkabau people. Up until now, the exact moment Islam was introduced into the Minangkabau remains a debatable issue. Some sources say that Muslim merchants introduced Islam in the seventh and eighth centuries AD from Arabia and Persia, while others state 